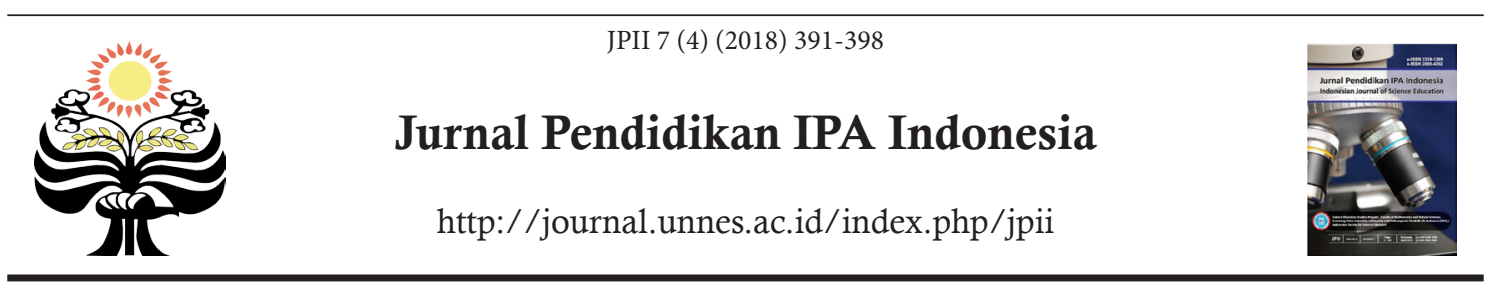

\title{
ELECTRONIC VERSUS PRINTED BOOK: A COMPARISON STUDY ON THE EFFECTIVITY OF SENIOR HIGH SCHOOL PHYSICS BOOK
}

\author{
A. Suyatna ${ }^{* 1}$, H. Maulina ${ }^{2}$, I. Rakhmawati ${ }^{3}$, R. A. N. Khasanah ${ }^{4}$ \\ ${ }^{1,2,3}$ Universitas Lampung, Lampung, Indonesia \\ ${ }^{4}$ Postgraduate Student of Tunghai University, Taiwan
}

DOI: 10.15294/jpii.v7i4.14437

Accepted: August 23 $3^{\text {rd }}, 2018$. Approved: December 10 ${ }^{\text {th }}, 2018$. Published: December 29 ${ }^{\text {th }}, 2018$

\begin{abstract}
This study aimed to examine the effectiveness of senior high school physics book both interactive electronic and printed, viewed from the difference in gender and material characteristics. The research used Quasi-Experimental Design with Non-Equivalent posttest-pretest control group design. The data were collected through physics tests from six senior high schools in Lampung Province, Indonesia and analyzed on ANOVA and multiple comparisons to determine the differences in learning outcomes (affectivity) and interaction between interactive electronic and printed, gender, and material characteristics. The results showed that there were different learning outcomes caused by interactive electronic and printed physics book $(p=0.000<0.05)$. The learning outcomes using interactive electronic books were better than using printed books for both male and female students while gender differences did not affect physics learning outcomes for both interactive electronic and printed books $(p=0.963>0.05)$. There was no interaction between interactive electronic and printed books and gender $(p=0.298>0.05)$. There are differences in learning outcomes caused by physical material characteristics $(p=0.000<0.05)$. Therefore, it concluded that the high school interactive physics electronic book was effectively used as a learning resource for both male and female students.
\end{abstract}

(C) 2018 Science Education Study Program FMIPA UNNES Semarang

Keywords: effectiveness interactive electronic book, gender, physics material characteristics

\section{INTRODUCTION}

Many factors could affect students' physics learning outcome, for example, learning resources, material characteristics, students' experience, motivation, teaching method, and the initial competence of students (Hänze \& Berger, 2007; Haycock, 2007). Commonly, schools use printed books as a learning resource which has been recommended by the Center of Curriculum and Books (Pusat Kurikulum dan Perbukuan), Ministry of Education and Culture. These books have been subject to content conformity with the existing curriculum. However, there has not been

*Correspondence Address

E-mail: asuyatna@yahoo.com any research or study on the conformity of the format and its form.

The government recommends electronic school books for use in schools and purchase copyright from authors. By this way, anyone can print and reproduce the book at the maximum price set by the government. Besides that, students are allowed to download these books in pdf format and use it as learning resources without paying (Andina, 2011). This policy will certainly help students in providing a good and affordable learning resource.

Nevertheless, the question is, why the average Indonesian student learning outcomes is still relatively low (data from PISA/Programme for International Student Assessment score). The 
data conclude the average score of Indonesia science literacy in 2015 was 403, and it belogs to rank 62 of 70 countries participant, while another ASEAN countries such as Vietnam is in the 8th rank and Thailand in the 54th. Further analysis of PISA in Indonesia, obtained the fact of the average future career field Indonesian children in science is $15.3 \%$ (boys $8.6 \%$, girls $22.1 \%$ ). Index of learning science motivation is 0.65 , whereas the average OECD is 0.02 . besides that, the difference of learning science motivation between boys and girls is -0.06 . This means that Indonesian girls enjoy learning science more than boys (OECD, 2015). This fact must be followed up with various studies that lead to increasein learning outcomes, of of them is concern in book form which become the main source of learning.

The use of learning resources become one factor which can influence the learning outcomes. Therefore, as the development of science and technology in the world, requires educators/teachers to modify the learning resource in the form of printed into unprinted. One of the most unprinted learning resources is an electronic-based book. Throughout the literature review, electronic-based books have been defined and described in numerous ways. Most research on electronic-based books defines them as texts that are digital and accessed via electronic screens. There are two formats in which electronic-based books. These are page fidelity and reflow-able digital electronic-based books (Jeong, 2012; Chesser, 2011; Salmon, 2014). Besides, many researchers in higher education have focused primarily upon faculty and student preferences of etextbook formats (Margolin et al., 2013; Kim \& Kim, 2013; Robinson, 2011; Jamali et al., 2010; Woody et al., 2010, Kang et al., 2009).

By using electronic-based books, many physical processes can be easily understood and visualized by students. Electronic based-book belongs to an interactive book because written in many kinds of color, some illustrations have a moving, sounds, animation, video, and film (Holaday et al., 2013; Ambarwati \& Suyatna, 2018; Suyatna et al., 2018). Electronic books are developed by using software, for example, the Learning Content Development System (LCDS). By using the interactive book, students are able to study by themselves, anywhere and anytime. In order to accommodate it, the interactive book must be created and designed to accommodate it. In preparing interactive book required adequate supporting knowledge, especially in operating equipment such as computers, video cameras, and photo cameras. Such kinds of book are im- portant to be developed in many kinds of subject, for example, physics.

Perhaps, through the use of LCDS-based learning module facilitates physics teacher in delivering physics concept, especially for an abstract concept. Therefore, it can improve students in understanding physics. Because the LCDS-based learning module is able to engage students to be active through the discovery process, and trigger the mindset of students in conceptualization (Nuralinda, 2017). Books developed using the LCDS are also attractive, easy to use, useful, and effective in improving student learning outcomes (Aulia et al., 2017).

Five kinds of the use of a computer in the learning process are drill and practice, tutorial program, demonstration, simulation, and instructional games (Hoseth \& McLure, 2012; Reynolds, 2011). The overall use of computer programs above can be seen in an LCDS-based book. LCDS makes it easy to publish e-learning with customizable content, interactive activities, quizzes, games, animations, videos, and other multimedia (Aremu, 2013). The LCDS application has several advantages, among them: (1) developing and publishing content quickly, timely and relevant; (2) delivering Web content in accordance with SCORM 1.2 and can be hosted in a learning management system; (3) uploading or publish existing content; (4) creating rich e-learning content based on Silverlight easily; (5) developing training structures and easily reorganize at any time; (6) developing learning books equipped with animation, images, videos, and interactive questions (Taufani \& Iqbal, 2011).

Personality and motivation play important roles in explaining gender differences in school attainment (Steinmayr \& Spinath, 2008). According to Huang et al. (2017), male and female are motivated differently when reconstructing their identities, a female is more focused on highlighting the physical situation, while a male emphasizes their achievement. At the age of 14-17, a person's typical characteristics begin to emerge, namely the nature of passive-accept for females and the active-doing for males. Therefore, the appearance of male's behavior seems more intense and explosive while female's behavior seems more controlled by feelings and tied to family traditions and rules (Kartono, 2017). Yukselturk \& Bulut (2009) analyzed gender differences in self-regulated learning components, motivational beliefs, and achievement in a self-regulated online learning environment. The results showed that test anxiety explained a large number of variants in female student achievement and two variables 
(self-efficacy for learning and performance, and task scores) explained a large number of variants in male student achievement. It was also found that there were no statistically significant mean differences between motivational beliefs, selfregulated learning variables, and achievement in gender programming. Besides, female students also have higher levels of test anxiety than male. It causes the lower course grades for female participants (Chinet al., 2017). They also suggested that the relationship between gender and negative affect may be a significant indicator of an individual's predisposition towards high test anxiety and poor course grades. Further added by the study of Yang et al. (2011), male students are spending more effort than female in online learning while female expend more energy than male on face-to-face learning. There are gender differences to emotional intelligence in some specific aspects (Lopez-Zafra et al., 2012).

Based on the above description, it concluded that gender and the utilization of learning resources is one of the factors that influence student learning outcomes. Therefore, every teacher in the school should have the ability to handle gender differences through the use of interactive learning resources, one of them through the interactive electronic learning of physics. In addition, it is also important to know whether interactive electronic books are suitable as a learning resource to present different physics learning materials.

With this in mind, this study aimed to examine the effectiveness of interactive electronic books of physics in terms of differences in format, gender, and material characteristics.

\section{METHODS}

The population of this study was all students of grade XI Senior High School in Lampung Province, Indonesia, year 2016/2017. The sample was chosen by purposive sampling as many as 12 equivalent classes. The first six classes study physics with a source of learning, interactive electronic books. Each class studied a different topic, namely: Elasticity and Hooke's Law, Kinematic, Simple Harmonic Motion, Heat, Impulse and Momentum, Work and Energy. The second six classes studied physics using the printed physics book published by Center of Curriculum and Books, Ministry of Education and Culture. The learning approach of all classes was the scientific approach.
To examine the differences in students' learning outcomes caused by the differences in the books form, gender, and the interaction between book form and gender, a factorial design was employed (Table 1).

Table 1. The Factorial Design (2x2)

\begin{tabular}{cllll}
\hline \multirow{2}{*}{$\begin{array}{c}\text { Attribute } \\
\text { E-book } \\
\text { Interactive } \\
\text { (EBI) }\end{array}$} & $\begin{array}{c}\text { Brinted } \\
\text { Book } \\
\text { (PB) }\end{array}$ & Total & \\
\hline Gender & $\begin{array}{l}\text { Male } \\
(\mathrm{M})\end{array}$ & M-EBI & M-PB & $\mathrm{M}$ \\
& $\begin{array}{l}\text { Female } \\
(\mathrm{F})\end{array}$ & F-EBI & F-PB & $\mathrm{F}$ \\
Total & & EBI & PB & \\
\hline
\end{tabular}

In this design, all of the classes were given pretest before treatment and posttest after treatment. The instruments for pretest and posttest were in the form of multiple choices which consisted of 10 items for each different materials or 60 items in total. The instruments had an average Normalized Gain of pre and post-test score (Marx \& Cummings, 2007). It was the differences of posttest and pretest score divided by the difference maximum score and pretest score.

A two-way ANOVA is useful when we desire to compare the effect of multiple levels of two factors and have multiple observations at each level (Wobbrock et al, 2011). In this study, the twoway ANOVA was used to examine the differences in learning outcomes caused by differences book form (electronic interactive and printed), gender differences (male and female) and the interaction between book form and gender. A One-way ANOVA test was conducted to examine the differences in learning outcomes caused by differences between the physics of interactive electronic books. The multiple comparison tests were performed to determine the physics materials that led to different learning outcomes.

\section{RESULTS AND DISCUSSION}

This research was preceded by the development of LCDS-based interactive electronic books as the learning source covering the topic of elasticity and Hooke's Law, heat, kinematics, simple harmonic motion, impulse and momentum, and work and energy for high school students. In the 
experimenalt class, the students used the offline LCDS-based interactive electronic book. They were required to access menus, do the simulation, play video, and do an interactive test as an exercise. Meanwhile, in the control class, the teacher taught the materials and student did the exercises in a printed physics book. The data analysis results of students' learning outcome in each topic and gender are shown in Table 2.

Table 2. The Students' Learning Outcome in Each Topic And Gender

\begin{tabular}{lcccc}
\hline \multirow{2}{*}{\multicolumn{1}{c}{ Topic }} & \multicolumn{4}{c}{ The Students' learning outcomes } \\
\cline { 2 - 5 } & Male (M) & Female (F) & Difference (M-F) & Total \\
\hline Elasticity and Hooke's Law & 80.83 & 73.33 & 7.50 & 75.83 \\
Kinematic & 80.00 & 75.83 & 4.17 & 78.00 \\
Simple Harmonic Motion & 73.75 & 66.82 & 6.93 & 68.67 \\
Heat & 83.56 & 80.83 & 2.72 & 81.88 \\
Impulse and Momentum & 74.67 & 70.94 & 3.73 & 72.74 \\
Work and Energy & 85.38 & 90.63 & -5.24 & 88.28 \\
\hline Total Average & 79.70 & 76.40 & 3.30 & 77.57 \\
\hline
\end{tabular}

Table 3. The Two-way Anova Analysis of Book Form and Gender

\begin{tabular}{lccccc}
\hline \multicolumn{1}{c}{ Source } & $\begin{array}{c}\text { Type III Sum of } \\
\text { Squares }\end{array}$ & df & Mean Square & F & p \\
\hline Corrected Model & $1.094^{\mathrm{a}}$ & 3 & 0.365 & 17.660 & 0.000 \\
Intercept & 12.876 & 1 & 12.876 & 623.290 & 0.000 \\
Book Form & 0.884 & 1 & 0.884 & 42.801 & 0.000 \\
Gender & $4.431 \mathrm{E}-5$ & 1 & $4.431 \mathrm{E}-5$ & 0.002 & 0.963 \\
Book & 0.023 & 1 & 0.023 & 1.101 & 0.298 \\
Form ${ }^{*}$ Gender & & & & & \\
\hline
\end{tabular}

The two-way ANOVA test results are presented in Table 3. The results of the difference between the N-Gain mean between the students (both male and female) using the interactive electronic book with students using printed books obtained $p=0.000$ less than $\alpha=0.05$. This elucidated that there was an average difference of the $\mathrm{N}$-Gain between the students who studied physics by using interactive electronic and printed books.

The students who used the interactive electronic book got higher learning outcomes than those utilizing the printed book. This finding confirms the research done by Rockinson-Szapkiw et al. (2012) stating that students who chose e-textbooks for their education courses had significantly higher perceived effective learning and psychomotor learning than students who chose to use traditional printed textbooks. This acquisition is possible because the interactive electronic book is equipped with animated physical phenomena for moving objects such as kinematics motion which is shown in the example of straight irregular motion, accelerated motion, parabolic motion, impulse and momentum, etc. Thus, ob- ject movement can be evaluated directly any time. Through animations, the students were able to differentiate between the harmonic and non-harmonic motion. These findings are supported by other research results, including the effects of dynamic visualization. Dynamic visualization for moving objects is better than static visualization so that the students' learning outcomes increased (Suyatna, et al., 2017; Chesser, 2011). This is in line with the research carried out by Suyatna et al. (2017) which showed that the N-gain average of students' learning outcomes using moving image-assisted was higher than a static object.

Media that integrates a combination of digital text, graphics, animation, and sound in physics learning could attract sight, stimulate students' learning motivation, and produce effective physics learning (Higgins et al., 2018; Faulconer et al., 2018). According to Lin (2009), the animation was created to convey the concept of change and was considered effective in expressing the process. The research results supported the findings that the students' learning outcomes whose learning process was supported by interactive 
electronic books equipped with animation and simulation of physics laboratory were better than the printed book. The higher learning results were caused by Indonesian printed books which lack experiment procedures. Bancong \& Song (2018) analyzed 30 physics textbooks from Grades 10 to 12 which are widely used both by teachers and students. The results showed that the majority of physics textbooks did not mention about thought experiments. Only 6 physics textbooks presented thought experiments at a satisfactory level.

LCDS software as a system development content of electronic learning materials very supports the arrangement and completeness of teaching materials. The LCDS could display text, images, animations, videos, experimental simulations, and quizzes, both online and offline. Experimental simulations contained in interactive electronic books strongly support problemsolving abilities. This is supported by the results of Gunawan et al. (2017) and Ebied \& Rahman (2015). According to Sjarif et al. (2016), the use of integrated modules using interactive lectures and workshops could improve students' understanding and skills.

Based on the two-way ANOVA analysis (Table 3), gender differences did not give significant differences in student learning outcomes. The average N-Gain of male students' learning outcomes was not significantly different at the 95\% confidence level compared to the N-Gain average of female students' learning outcomes, both in students using interactive electronic and printed physics books $(p=0.963>0.05)$. Male students studied physics as well as female students. Although there was a difference in sciencelearning motivation between boys and girls, where Indonesian girls enjoy learning science more than boys, the interaction between male and female students during the classroom learning process reduced the differences (OECD, 2015). This finding is different from the research performed by Sahal (2016), male students' learning outcomes were better compared to male students' learning outcomes. This research was conducted on boarding schools where male and female students were separated so that during the learning process, there was no interaction between male and female students. However, this finding also confirms the research result of Hoogerheide et al. (2016) which concluded that gender does not affect learning outcomes, but may influence affective aspects of learning.

The result of two-way ANOVA analysis on the interaction between book format and gender resulted in sig value or probability $p=0.298>$ 0.05 . It shows that there was no interaction between book form and gender. Thus, both male and female students could use either electronic or printed books. The results showed that students physics learning outcomes would be better if their learning was supported by interactive electronic books, both for male and female students when compared by using physics printed book.

The results of one-way ANOVA analysis elucidated that there were differences in learning outcomes seen from the characteristics of physics materials (Table 4).

Table 4. One-Way Anova Analysis for Interaction between Different Physics Learning Materials and Students' Learning Outcomes

\begin{tabular}{lccccc}
\hline \multicolumn{1}{c}{ Source } & $\begin{array}{c}\text { Type III Sum of } \\
\text { Squares }\end{array}$ & df & Mean Square & F & p \\
\hline Corrected Model & $8380.64^{\mathrm{a}}$ & 11 & 761.877 & 7.730 & 0.000 \\
Intercept & 1022761.44 & 1 & 1022761.44 & 10376.81 & 0.000 \\
Material Characteristic & 5746.701 & 5 & 1149.340 & 11.661 & 0.000 \\
Error & 16952.688 & 172 & 98.562 & & \\
Total & 135644.64 & 184 & & & \\
Corrected Total & 25333.333 & 183 & & & \\
\hline
\end{tabular}

a. R Squared $=.331$ (Adjusted R Squared $=.288$ )

Further analysis was done to see an increase in the average learning outcomes on different physics materials. A multiple comparison analysis was used for this (Table 5). Based on the results in Table 5, there were different physics learning outcomes between elasticity and Hooke's Law materials; elasticity and Hooke's
Law with Work \& Energy; Motion Kinematics and Simple Harmonic Motion; Motion Kinematics and Work \& Energy; Simple Harmonic Motion and Heat; Simple harmonic motion and Work \& Energy; Heat and Impulse \& Momentum; Impulse \& Momentum and Work \& Energy. Overall, there were seven pairs of different learning 
outcomes occurred. These differences could be evaluated through its mean differences.

The students' learning outcomes on Work \& Energy were higher than Elasticity and Hooke's Law topic. The concept of elastic modulus was still considered difficult by the students since it involved abstract concepts. This is in contrast to the concept of Work \& Energy whose examples could be found in daily life. Therefore, it is facile to visualize and simulated. The Kinematics materials are easier than the Harmonic Motion materials although both topics are easily visualized, Kinematics materials are simpler to be represented in various forms.

Table 5. The Students' Learning Outcomes Using Multiple Comparison Test in Different Learning Materials

\begin{tabular}{|c|c|c|c|}
\hline $\begin{array}{l}\text { (I) } \\
\text { MK }\end{array}$ & $\begin{array}{l}\text { (J) } \\
\text { MK }\end{array}$ & $\begin{array}{c}\text { Mean } \\
\text { Difference }\end{array}$ & $\mathbf{p}$ \\
\hline \multirow[t]{5}{*}{ EHL } & K & -2.1697 & 0.966 \\
\hline & SHM & 7.1637 & 0.063 \\
\hline & $\mathrm{H}$ & -6.0504 & 0.127 \\
\hline & IM & 3.0884 & 0.829 \\
\hline & WE & $-12.4455^{*}$ & 0.000 \\
\hline \multirow[t]{4}{*}{ K } & SHM & $9.3333^{*}$ & 0.008 \\
\hline & $\mathrm{H}$ & -3.8808 & 0.648 \\
\hline & $\mathrm{IM}$ & 5.2581 & 0.364 \\
\hline & WE & $-10.2759^{*}$ & 0.003 \\
\hline \multirow[t]{3}{*}{ SHM } & $\mathrm{H}$ & $-13.2141^{*}$ & 0.000 \\
\hline & IM & -4.0753 & 0.598 \\
\hline & WE & $-19.6092^{*}$ & 0.000 \\
\hline \multirow[t]{2}{*}{$\mathrm{H}$} & IM & $9.1388^{*}$ & 0.002 \\
\hline & WE & -6.3951 & 0.096 \\
\hline IM & WE & $-15.5339^{*}$ & 0.000 \\
\hline
\end{tabular}

*) significant different at $95 \%$

EHL is Elasticity and Hooke's Law, $\mathrm{K}$ is Kinematic, SHM is Simple Harmonic Motion, $\mathrm{H}$ is Heat, IM is Impuls and Momentum, WE isWork and Energy

The Heat materials were felt easier than Simple Harmonic Motion since the Heat concept was frequently encountered by the students in everyday life. The average difference in learning outcomes for each physics topic was due to differences in material characteristics, and the development quality of interactive electronic books. A good interactive electronic book should have several criteria including the concepts, principles, formulas, and laws which are systematically arranged and supported by images, animations, videos, experimental simulations, and interactive exercise questions.

It cannot deny that each of physics topic has a different difficulty level. There were several topics that can be directly observed, done and learned in the learning so that the students are easier to understand and apply it. However, some other topics are arduously understood as they could not do direct experiments in the learning process. Although computer-aid was utilized, there was a time that the students had to imagine what happens. this imagining skill may vary to each student which; therefore, ultimately affect their learning outcomes.

\section{CONCLUSION}

Based on the results and discussions, it concluded that there were differences in physics learning outcome caused by different book forms. The students' learning outcomes using interactive electronic books were higher than printed books. Meanwhile, there was no difference in the average of physics learning outcomes caused by gender both in the experimental and control class. Male students' learning outcomes were not significantly different from female students. Besides, there was no interaction between the interactive electronic book form with gender in terms of learning outcomes, but there was a difference in physics learning outcomes caused by the distinct characteristics of interactive electronic books. These also indicated that interactive electronic books are feasible as a learning resource to present different physics learning materials.

\section{REFERENCES}

Aremu, A., \& Efuwape, B. M. (2013). A Microsoft Learning Content Development System (LCDS) Based Learning Package for Electrical and Electronics Technology-Issues on Acceptability and Usability in Nigeria. American Journal Of Education Research, 1(2), 41-48.

Ambarwati, D., \& Suyatna, A. (2018, January). Interactive design for self-study and developing students' critical thinking skills in electromagnetic radiation topic. In Journal of Physics: Conference Series (Vol. 948, No. 1, p. 012039). IOP Publishing.

Andina, E. (2011). Buku Digital dan Pengaturannya. Jurnal Aspirasi, 2(1), 79-95.

Aulia, MK., Suyatna, A. \&Sesunan, F. (2017). Pengembangan Modul Pembelajaran Menggunakan Learning Content Development System (LCDS) Materi Kinematika Gerak. Jurnal Pembelajaran Fisika, 5(5), 97-109. 
Bancong, B., \& Song, J. Do Physics Textbooks Present the Ideas of Thought Experiments?: A Case in Indonesia. Jurnal Pendidikan IPA Indonesia, 7(1), 25-33.

Chesser, W. D. (2011). The E-Textbook Revolution. Library Technology Reports, 47(8), 28-40.

Chin, E. C., Williams, M. W., Taylor, J. E., \& Harvey, S. T. (2017). The Influence of Negative Affect on Test Anxiety and Academic Performance: An Examination of the Tripartite Model of Emotions. Learning and Individual Differences, $54,1-8$.

Ebied, M. M. A., \& Rahman, S. A. A. (2015). The Effect of Interactive E-Book on Students' Achievement at Najran University in Computer in Education Course. Journal of Education and Practice, 6(19), 71-82.

Faulconer, E. K., Griffith, J., Wood, B., Acharyya, S., \& Roberts, D. (2018). A Comparison of Online, Video Synchronous, and Traditional Learning Modes for an Introductory Undergraduate Physics Course. Journal of Science Education and Technology, 1-8.

Gunawan, G., Harjono, A., Sahidu, H., \& Herayanti, L. (2017). Virtual Laboratory to Improve Students' Problem-Solving Skills on Electricity Concept. Jurnal Pendidikan IPA Indonesia, 6(2), 257-264.

Hänze, M., \& Berger, R. (2007). Cooperative Learning, Motivational Effects, and Student Characteristics: An Experimental Study Comparing Cooperative Learning and Direct Instruction in 12th Grade Physics Classes. Learning and Instruction, 17(1), 29-41.

Haycock, K. (2007). Collaboration: Critical Success Factors for Student Learning. School Libraries Worldwide, 13(1), 25.

Higgins, J., Moeed, A., \& Eden, R. (2018). Video as a Mediating Artefact of Science Learning: Cogenerated Views of What Helps Students Learn From Watching Video. Asia-Pacific Science Education, 4(1), 6-16.

Holaday, L., Selvig, D., Purkiss, J., \& Hortsch, M. (2013). Preference of Interactive Electronic Versus Traditional Learning Resources by University of Michigan Medical Students during the First Year Histology Component. Medical Science Educator, 23(4), 607-619.

Hoogerheide, V., Loyens, S. M., \& van Gog, T. (2016). Learning from Video Modeling Examples: Does Gender Matter?. Instructional Science, 44(1), 69-86

Hoseth, A. E., \& McLure, M. (2007). Perspectives on E-books from Instructors and Students in The Social Sciences. Reference \& User Services Quarterly, 51(3), 278-288.

Huang, J., Kumar, S., \& Hu, C. (2018). Gender Differences in Motivations for Identity Reconstruction on Social Network Sites. International Journal of Human-Computer Interaction, 34(7), 591-602.
Jamali, H. R., Nicholas, D., \& Rowlands, I. (2010). Scholarly E-books: The Views of 16,000 Academics. New Information Perspectives, 61(1), 3347.

Jeong, H. (2012). A Comparison of the Influence of Electronic Books and Paper Books on Reading Comprehension, Eye Fatigue, and Perception. The Electronic Library, 30(3), 390-408.

Kang, Y. Y., Wang, M. J. J., \& Lin, R. (2009). Usability Evaluation of E-books. Displays, 30(2), 49-52.

Kartono, K. (2007). Psikologi Anak (Psikologi Perkembangan). Bandung: Mandar Maju.

Kim, H., \& Kim, J. O. A. N. (2013). Reading from an LCD Monitor Versus Paper: Teenagers' Reading Performance. International Journal of Research Studies in Educational Technology, 2(1), $1-10$.

Lin, C. C. (2009). Learning Action Verbs with Animation. The Jalt Call Journal, 5(3), 23-40.

Lopez-Zafra, E., Garcia-Retamero, R., \& Martos, M. P. B. (2012). The Relationship Between Transformational Leadership And Emotional Intelligence from a Gendered Approach. The Psychological Record, 62(1), 97-114.

Margolin, S. J., Driscoll, C., Toland, M. J., \& Kegler, J. L. (2013). E-readers, Computer Screens, or Paper: Does Reading Comprehension Change Across Media Platforms?. Applied Cognitive Psychology, 27(4), 512-519.

Marx, J. D., \& Cummings, K. (2007). Normalized change. American Journal of Physics, 75(1), 8791.

Nuralinda, Y., Nyeneng, I. D. P., \& Suana, W. (2017). Implementasi Modul Pembelajaran Berbasis LCDS untuk Meningkatkan Penguasaan Konsep Siswa SMA. Jurnal Pembelajaran Fisika, 5(5). 45-55.

OECD. (2015). Programme for International Student Assessment (PISA) Results form PISA 2015. Retrieved from: http://www.oecd.org/pisa/ PISA-2015-Indonesia.pdf.

Reynolds, R. (2011). Trends Influencing the Growth of Digital Textbooks in US Higher Education. Publishing Research Quarterly, 27(2), 178-187.

Robinson, S. (2011). Student Use of a Free Online Textbook. Academy of Educational Leadership Journal, 15(3), 1-10.

Rockinson-Szapkiw, A. J., Courduff, J., Carter, K., \& Bennett, D. (2013). Electronic Versus Traditional Print Textbooks: A Comparison Study on the Influence of University Students' Learning. Computers \& Education, 63, 259-266.

Sahal, M. (2016). Hasil Belajar Fisika dan Aktivitas Siswa berdasarkan Gender melalui Penerapan Model Pembelajaran Kolaboratif pada Materi Pokok Optik di Kelas X MA Al-Ihsan Boarding School Kampar. Jurnal Online Mahasiswa (JOM) Bidang Keguruan dan Ilmu Pendidikan, 3(1), 1-10.

Salmon, L. G. (2014). Factors that Affect Emergent Literacy Development when Engaging with 
Electronic Books. Early Childhood Education Journal, 42(2), 85-92.

Sjarif, D. R., Yuliarti, K., Wahyuni, L. K., Wiguna, T., Prawitasari, T., Devaera, Y., ... \& Afriansyah, A. (2016). Effectiveness of a Comprehensive Integrated Module Using Interactive Lectures and Workshops in Understanding and Knowledge Retention about Infant Feeding Practice in Fifth Year Medical Students: A QuasiExperimental Study. BMC Medical Education, 16(1), 210-222.

Steinmayr, R., \& Spinath, B. (2008). Sex Differences in School Achievement: What are the Roles of Personality and Achievement Motivation?. European Journal of Personality: Published for the European Association of Personality Psychology, 22(3), 185-209.

Suyatna, A., Distrik, I. W., Herlina, K., Suyanto, E., \& Haryaningtias, D. (2018, September). Developing Interactive E-Book of Relativity Theory to Optimize Self-Directed Learning and Critical Thinking Skills. In AIP Conference Proceedings (Vol. 2014, No. 1, p. 020065). AIP Publishing.

Suyatna, A., Anggraini, D., Agustina, D., \&Widyastuti, D. (2017). The Role of Visual Representation in Physics Learning: Dynamic Versus
Static Visualization. Journal of Physics: Conference Series, 909, 1-8.

Taufani, D. R., \& Iqbal, M. (2011). Membuat Konten E-learning dengan Microsoft Learning Content Development System (LCDS). Bandung: Universitas Komputer Indonesia.

Wobbrock, J. O., Findlater, L., Gergle, D., \& Higgins, J. J. (2011). The Aligned Rank Transform for Nonparametric Factorial Analyses Using Only Anova Procedures. In Proceedings of the SIGCHI Conference on Human Factors In Computing Systems (pp. 143-146). ACM.

Woody, W. D., Daniel, D. B., \& Baker, C. A. (2010). Ebooks or Textbooks: Students Prefer Textbooks. Computers \& Education, 55(3), 945-948.

Yang, Y., Cho, Y., Mathew, S., \& Worth, S. (2011). College Student Effort Expenditure in Online Versus Face-To-Face Courses: The Role of Gender, Team Learning Orientation, and Sense of Classroom Community. Journal of Advanced Academics, 22(4), 619-638.

Yukselturk, E., \& Bulut, S. (2009). Gender Differences in Self-Regulated Online Learning Environment. Educational Technology \& Society, 12(3), 12-22. 